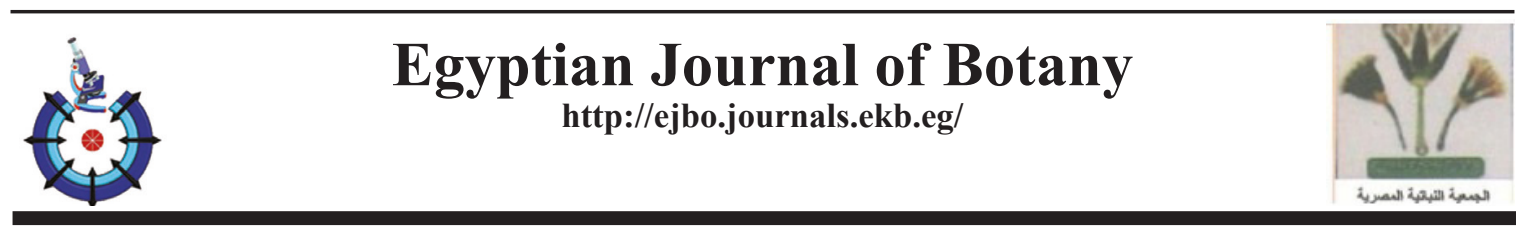

\title{
Zinc Oxide Nanoparticles Induce Changes in the Antioxidant Systems and Macromolecules in the Solanum nigrum Callus
}

Dalia A. Abdel-Wahab(1)\#, Nasim A.R.M. Othman ${ }^{(2)}$, Afaf M. Hamada ${ }^{(2)}$

(1)Botany and Microbiology Department, Faculty of Science, New Valley University, El Kharga, Egypt; ${ }^{(2)}$ Botany and Microbiology Department, Faculty of Science, Assiut University, Assiut 71516, Egypt.

\begin{abstract}
T THIS STUDY aimed to explore the effects of zinc oxide nanoparticles ( $\mathrm{ZnO} \mathrm{NPs)} \mathrm{on}$ physiological parameters of Solanum nigrum calli and the possibility of using it as a remediator for contaminated media. In vitro experiments were conducted to understand the mechanism of $S$. nigrum in the remediation of $\mathrm{ZnO} N$ Ps $\left(0,50\right.$ and $100 \mathrm{mg} \mathrm{L}^{-1}$ used). The dry weight of calli subjected to the lowest concentration of ZnO NPs was increased (1.8 fold higher than the control). The activities of lipoxygenase and antioxidant enzymes in the callus were stimulated at the highest level of ZnO NPs. The treatment of ZnO NPs did not change the activity of phenylalanine ammonia-lyase and phenolic compounds while reducing the activity of polyphenol oxidase. The contents of phosphorus and potassium were decreased under $\mathrm{ZnO}$ NPs treatments. Amino acids, soluble proteins, soluble carbohydrates, and $\mathrm{Zn}$ content were elevated in the $\mathrm{ZnO}$ NPs-treated-callus. The infrared spectroscopy analysis proved the differences between most macromolecules. The results indicate that this plant can be used in the remediation of $\mathrm{ZnO}$ NPs in the contaminated media.
\end{abstract}

Keywords: Antioxidant system, Macromolecules, Nanoparticles, Phytoremediation, Solanum nigrum, Zinc oxide.

\section{Introduction}

Nanoparticles (NPs) from natural and anthropogenic sources can appear in the soil (Morales-Díaz et al., 2017; Kumar et al., 2019). Nowadays, NPs have been widely used in various products and industries, however, their release into the environment threatens living organisms (Zafar et al., 2016).

Entry and toxicity concerning NPs to plants rely on the chemical construction and size that impacts the ligand-receptor interactions (Raliya et al., 2016). ZnO NPs are significantly used in various products as well as in the agriculture and food sector, like pesticides, fungicides, and fertilizers (Ghosh et al., 2016 ; Housseiny \& Gomaa, 2019). The toxic impact of NPs has been reported as a result of size, morphology, nature, composition, reactivity, and other NPs capacities (Zaka et al.,
2016). Subsequently, phytotoxicity mechanisms regarding NPs ought to be quite realized earlier than application in the fields. The utmost ordinarily applied nanoparticles in a diversity of usage are ZnO NPs (Ju-Nam \& Lead, 2008) that elevated the possibility of direct release to ecosystems, leading to an ecological risk of $\mathrm{ZnO}$ NPs. It was reported that ZnO NPs reduced chlorophylls and photosynthetic capacity, whereas it stimulated the transcription of genes linked to the antioxidant capacity in tomato plants (Wang et al., 2018). Furthermore, in Allium cepa $\mathrm{ZnO}$ NP toxicity induced fragmentation to DNA (Ghosh et al., 2016).

Phytoremediation using the outstanding ability of plants to uptake heavy metals and compounds from environments and metabolize these diverse molecules between their tissues appears promising to decontaminate the pollutedenvironments (Garbisu \& Alkorta, 2003). The

\#Corresponding author emails: peautyrose@yahoo.com; dalia.abdelwahab@scinv.au.edu.eg

Dr. Nasim A.R.M. Othman email: adiminas@hotmail.com, Tel.: +201063528930

Dr. Afaf. M. Hamada email: afafhamada@yahoo.com; hamada@aun.edu.eg Tel.:+201006544540, Fax:+2088342708

Received 16/11/2019; Accepted 4/3/2020

DOI : 10.21608/ejbo.2020.19649.1391

Edited by: Prof. Dr. Wedad Kasim,Faculty of Science, Tanta University, Tanta, Egypt.

C2020 National Information and Documentation Center (NIDOC) 
use of vegetation to remove pollution from the surrounding has attracted a lot of attention as a low-expense and intimately to reclaim the contaminated environment (Pilon-Smits, 2005). The efficiency phytoremediation depends on the valid chosen of domestic plant varieties, typically with hyperaccumulators, which may enlarge on the soil of marginal finesse like richness, generation, construction of soils and metals existing (Mkumbo et al., 2012).

Solanum nigrum L. is a widespread and comparatively rapid-growing herb located in many tree regions and polluted environments (Särkinen et al., 2018). Furthermore, it is utilized as a medicinal plant and food in some countries (Rehman et al., 2017). In addition, it has been stated that it has the ability to accumulate heavy metals like $\mathrm{Cd}, \mathrm{Zn}$, and $\mathrm{Cu}$ in its tissues (Marques et al., 2006; Abdel-Wahab et al., 2019). Nonetheless, there is a lack of data about the efficiency of $S$. nigrum for the phytoremediation regarding $\mathrm{ZnO}$ NPs-contaminated surroundings and mechanisms concerned the toleration.

To study the efficacy of $S$. nigrum L. in tolerating $\mathrm{ZnO} \mathrm{NPs}$, in vitro $S$. nigrum callus was used. The effect of ZnO NPs on growth, antioxidative responses, accumulation of certain minerals, and Fourier transform infrared spectroscopy (FT-IR) functional groups were assessed. The quantification of $\mathrm{Zn}$ accumulation was also performed to affirm if this plant can be used for the phytoremediation of $\mathrm{ZnO}$ NPs.

\section{Materials and Methods}

\section{Preparation of $\mathrm{ZnO}$ NPs solution}

$\mathrm{ZnO}$ NPs $\left(<100 \mathrm{~nm}, 15-25 \mathrm{~m}^{2} \mathrm{~g}^{-1}\right.$ surface area and $99.5 \%$ purity; Sigma-Aldrich) were dissolved in distilled $\mathrm{H}_{2} \mathrm{O}$ and sonicated $(100 \mathrm{~W}, 40 \mathrm{kHz})$ for $30 \mathrm{~min}$.

\section{Plant tissue culture}

The culture medium composed of $4.4 \mathrm{~g} / \mathrm{L} \mathrm{MS}$ medium (Murashige \& Skoog, 1962), 3\% sucrose, $1 \mathrm{mg} / \mathrm{L} \alpha$-naphthalene acetic acid (NAA), different concentrations of the earlier prepared $\mathrm{ZnO}$ NPs $\left(0,50\right.$ and $100 \mathrm{mg} \mathrm{L}^{-1}$, which were selected from preliminary experiments) and $0.3 \%$ gelrite that was added after adjusting the $\mathrm{pH}$ of the medium to 5.7 . The culture medium was autoclaved for $15 \mathrm{~min}$ at $121^{\circ} \mathrm{C}$ temperature and $105 \mathrm{kPa}$ pressure and cooled to room temperature.
Young shoots were collected from wild $S$. nigrum herbs grown in Assuit Governorate $\left(27^{\circ} 11^{\prime} 00^{\prime \prime} \mathrm{N} \quad 31^{\circ} 10^{\prime} 00^{\prime \prime} \mathrm{E}\right)$. The leaves were washed under running tap water for regarding 20min, sterilized with $50 \%$ commercial bleach containing a few drops of Tween-20 for $8 \mathrm{~min}$ and then washed for 4-6 times using sterile distilled $\mathrm{H}_{2} \mathrm{O}$. In a $195 \mathrm{ml}$ jar, three sterilized $(1-1.5 \mathrm{~cm})$ leaf segments were placed on $30 \mathrm{ml}$ solidified MS media that previously prepared. Twenty jars were used per each treatment. These culture media were transferred to the growth chamber [16/8hrs photoperiod $30 \mu \mathrm{M} \mathrm{m}^{-2} \mathrm{~S}^{-1}$ irradiance, temperature $25 \pm 1{ }^{\circ} \mathrm{C}$ and $50-60 \%$ relative humidity] (AbdelWahab et al., 2019). After one-month, some calli were quickly weighed to determine the fresh weight $(\mathrm{FW})$, frozen in liquid nitrogen and stored at $-80^{\circ} \mathrm{C}$ for physiological parameters analysis. The other calli were dried at $60^{\circ} \mathrm{C}$ for $48 \mathrm{hrs}$ to determine the dry weight (DW) and some minerals.

\section{The activity of enzymes}

Frozen calli $(0.5 \mathrm{~g})$ were ground to a fine powder in liquid $\mathrm{N}_{2}$ and homogenized in $5 \mathrm{ml}$ of $100 \mathrm{mM}$ potassium phosphate buffer $(\mathrm{pH}$ 7.8) containing $0.1 \mathrm{mM}$ ethylenediaminetetraacetic acid (EDTA) and $0.1 \mathrm{~g}$ polyvinylpyrrolidone (PVP). The homogenate was filtered by centrifuge $(18,000 \mathrm{rpm}$ at $4{ }^{\circ} \mathrm{C}$ ) for $10 \mathrm{~min}$ and then the supernatant was used for the evaluation of enzymes and some metabolites. All enzyme activities were measured using a Unico UV-2100 spectrophotometer and the data were expressed as the difference in absorbance of wavelengths (DA).

Lipoxygenase (LOX; EC 1.13.11.12) activity was evaluated following the technique of Minguez-Mosquera et al. (1993). The activity was measured at $234 \mathrm{~nm}$ and expressed as $\mathrm{DA}_{234} \mathrm{mg}$ protein $^{-1} \min ^{-1}$.

Superoxide dismutase (SOD; EC 1.15.1.1) activity was assayed following the autoxidation of epinephrine as described by Misra \& Fridovich (1972). The activity was measured as an increase in absorbance at $480 \mathrm{~nm}$ and expressed as $\mathrm{DA}_{480} \mathrm{mg}$ protein $^{-1} \mathrm{~min}^{-1}$.

The activity of catalase (CAT; 1.11.1.6) was assayed following the consumption of $\mathrm{H}_{2} \mathrm{O}_{2}$ for $1 \mathrm{~min}$ as described by the method of Aebi (1984). The activity was calculated as a reduction in absorbance at $240 \mathrm{~nm}$ and expressed as $\mathrm{DA}_{240} \mathrm{mg}$ protein $^{-1} \min ^{-1}$. 
Peroxidase activity (POD; EC 1.11.1.7) was measured spectrophotometrically following the method of Tatiana et al. (1999). The formation of tetraguaiacol was measured at $470 \mathrm{~nm}$ and expressed as $\mathrm{DA}_{470} \mathrm{mg}$ protein ${ }^{-1} \mathrm{~min}^{-1}$.

The activity of phenylalanine ammonialyase (PAL; EC 4.3.1.5) was assayed following the production of trans-cinnamate as described by Havir \& Hanson (1968). The activity was calculated at $290 \mathrm{~nm}$ and expressed as $\mathrm{DA}_{290} \mathrm{mg}$ protein $^{-1} \min ^{-1}$.

The activity of polyphenol oxidase (PPO; EC 1.14.18.1) was evaluated via the formation of purpurogallin namely explained by Kumar \& Khan (1982). The activity was measured as an alteration of absorbance at $495 \mathrm{~nm}$ and expressed as $\mathrm{DA}_{495} \mathrm{mg}$ protein ${ }^{-1} \mathrm{~min}^{-1}$.

\section{Free and bound phenolics}

Free and cell wall-bound phenolics were assessed following the technique of Kofalvi \& Nassuth (1995). Phenolics were measured from the gallic acid standard curve and expressed as $\mu \mathrm{g} / \mathrm{g} \mathrm{FW}$.

\section{Free amino acids}

Free amino acids were assayed through the ninhydrin method using glycine as a standard amino acid according to Moore \& Stein (1948) and calculated as $\mathrm{mg} / \mathrm{g} \mathrm{FW}$.

\section{Soluble proteins}

Soluble proteins were measured by Folin reagent according to Lowry et al. (1951). A calibration curve was constructed using bovine serum albumin (BSA) and data were expressed as $\mathrm{mg} \mathrm{BSA} / \mathrm{g} \mathrm{FW}$.

\section{Soluble carbohydrates}

Soluble carbohydrates were measured according to the anthrone sulphuric acid method of Fales (1951) and Schlegel (1956) using glucose as a standard curve and expressed as mg/g FW.

\section{Zinc, potassium, and phosphorus}

The acid digested sample (1:3:1 ratio of $60 \%$ $\mathrm{HClO}_{4}$, concentrated $\mathrm{HNO}_{3}$ and $\mathrm{H}_{2} \mathrm{SO}_{4}$ ) was analyzed for $\mathrm{K}$ using flame photometer Carl Zeiss; for $\mathrm{Zn}$ using atomic absorption spectrophotometry (Buck model 210 Vgp, USA) (Radi et al., 2018), while $\mathrm{P}$ was determined using the technique of Woods \& Mellon (1941).
Fourier transform infrared (FT-IR)

The oven-dried sample $(\sim 100 \mu \mathrm{g})$ was prepared to identical thickness pellets using potassium bromide $(\mathrm{KBr})$. Infrared transmittance data were measured using Nicolet IS 10 FT-IR wave numbers ranged from $4000-400 \mathrm{~cm}^{-1}$. The sample was analyzed with plain $\mathrm{KBr}$ pellet as a blank and the data were compared with a reference to identify the functional groups in the sample.

\section{Statistical analysis}

Data were analyzed using one-way variance analysis (ANOVA) with Tukey's as post-hoc analysis. The relationship between the different parameters of the tested plant was analyzed using Pearson's correlation. Asterisks indicate a significant correlation (* and $* *$ at 5 and $1 \%$, respectively). All values are means of four independent replicates and analyzed using SPSS version 22 .

\section{Results}

Effects of ZnO NPs on biomass

Different $\mathrm{ZnO}$ NPs concentrations caused variable effects on callus growth (Fig. 1). The treatment of S. nigrum calli with $50 \mathrm{mg} \mathrm{L}^{-1}$ showed a significant increase in DW, and the increase was about $80 \%$, over the control. On the other hand, the $100 \mathrm{mg} \mathrm{L}^{-1} \mathrm{ZnO}$ NPs treatment reduced callus tissues DW by $30 \%$, relative to the control.

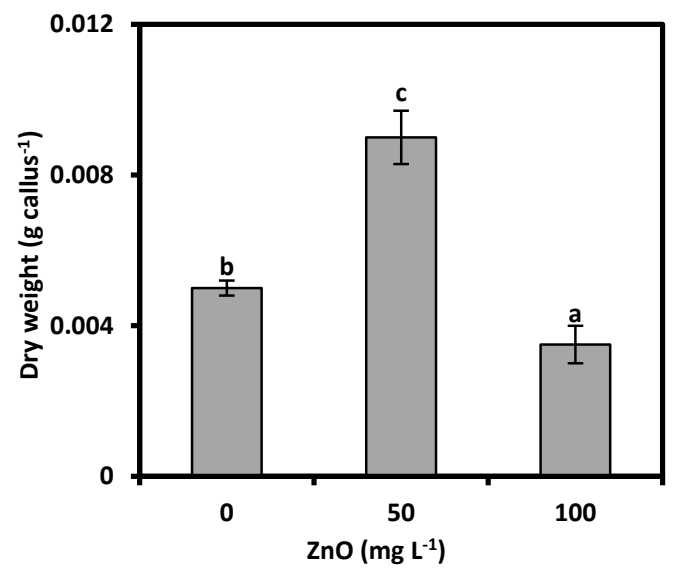

Fig. 1. The dry weight of $S$. nigrum callus grown under different concentrations of $\mathrm{ZnO}$ NPs $\left(0,50\right.$, and $\left.100 \mathrm{mg} \mathrm{L}^{-1}\right)$ [The data are means \pm SD $(n=4)$ [Different letters indicate statistically significant differences according to the Tukey's HSD test $(\mathrm{P} \leq 0.05)]$. 
Effects of ZnO NPs on the specific activity of enzymes

Figure 2A showed LOX activity in callus tissues of $S$. nigrum that differs with the various concentrations of $\mathrm{ZnO}$ NPs. Non-significant variations in the activity of LOX were observed in tissues due to the application of $50 \mathrm{mg} \mathrm{L}^{-1}$, compared with the control. However, LOX activity in calli was considerably increased by applying $100 \mathrm{mg} \mathrm{L}^{-1} \mathrm{ZnO}$ that showed an $82.37 \%$ increase over the control. It is important to note that LOX activity was non-significant correlated with the DW (-0.539), whereas it was strongly correlated
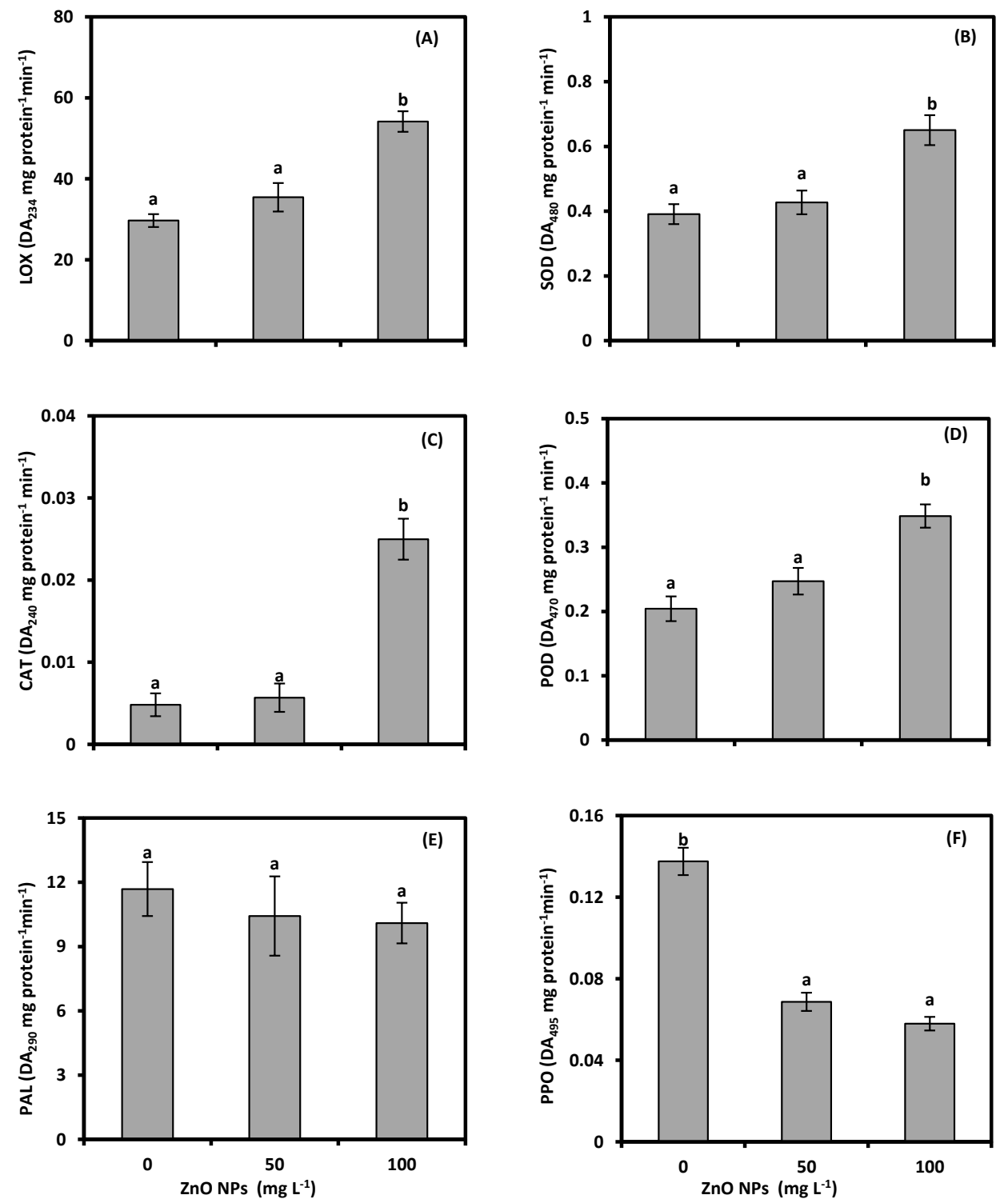

Fig. 2. Lipoxygenase (LOX; A), superoxide dismutase (SOD; B), catalase (CAT; C), peroxidase (POD; D), phenylalanine ammonia-lyase (PAL; E), and polyphenol oxidase (PPO; F) activities of $S$. nigrum callus grown under different concentrations of $\mathrm{ZnO}$ NPs $\left(0,50\right.$, and $\left.100 \mathrm{mg}^{-1}\right)$ [The data are means \pm SD $(n=4)$. Different letters indicate statistically significant differences according to the Tukey's HSD test $(\mathbf{P} \leq \mathbf{0 . 0 5})]$. 
The concentration of $50 \mathrm{mg} \mathrm{L}^{-1} \mathrm{ZnO}$ NPs insignificantly increased the activity of CAT, whereas a higher increase in CAT activity was recorded (419.39\% over the control) at $100 \mathrm{mg} \mathrm{L}^{-1}$ (Fig. 2C). The activity of the CAT was considerably correlated $\left(0.929^{* *}\right)$ with the $\mathrm{Zn}$ content of the callus.

Similar to the previous antioxidant enzymes, no considerable alteration in POD activity in $S$. nigrum calli was determined with the existence of $50 \mathrm{mg} \mathrm{L}^{-1} \mathrm{ZnO}$ NPs within the medium, while the activity raised with the rising of NPs in the media to $100 \mathrm{mg} \mathrm{L}^{-1}$ to achieve $70.63 \%$ over the control (Fig. 2D). Furthermore, the results revealed that the activity of POD was significantly correlated with the $\mathrm{Zn}$ content of callus tissues $\left(0.955^{* *}\right)$.

Effects of ZnO NPs on free and bound phenolics and associated enzymes

Results concerning the different concentrations of $\mathrm{ZnO}$ NPs on PAL activity in S. nigrum calli were given in Fig. 2E. No significant changes in
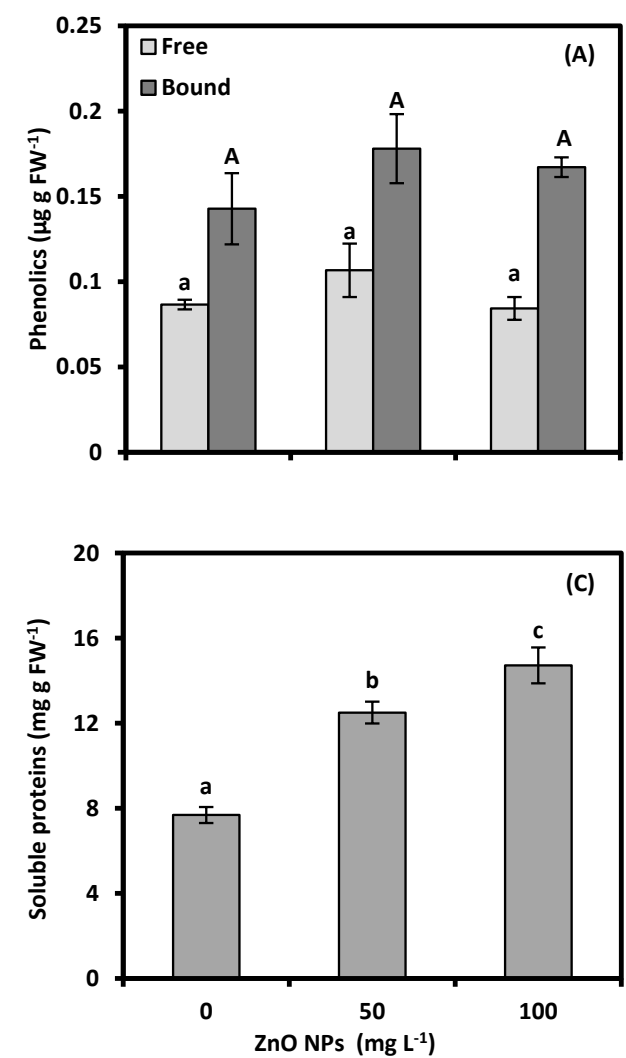

PAL activity were observed when the callus was exposed to $\mathrm{ZnO}$ NPs. The data revealed that PAL activity was only correlated with bound phenolics $\left(-0.786^{*}\right)$.

Concerning the effects of $\mathrm{ZnO}$ NPs on PPO activity, Fig. 2F showed that $\mathrm{ZnO}$ NPs treatments reduced the activity of PPO by 50.07 and $57.88 \%$, after calli exposure to 50 and $100 \mathrm{mg} \mathrm{L}^{-1}$, respectively, as compared with controls. Moreover, the results indicated a significant negative correlation between PPO activity and the content of $\mathrm{Zn}$ in calli $\left(-0.824^{* *}\right)$.

The content of free and bound phenolics in calli of $S$. nigrum was non-significantly affected by exposure to the different concentrations of $\mathrm{ZnO} \mathrm{NPs}$, as compared with the control (Fig. 3A). Treatment with ZnO NPs showed a strong correlation between free phenolics and DW $\left(0.758^{*}\right)$, while bound phenolics represented strong negative correlations with PAL and PPO activities $\left(-0.786^{*}\right.$ and $-0.668^{*}$, respectively).
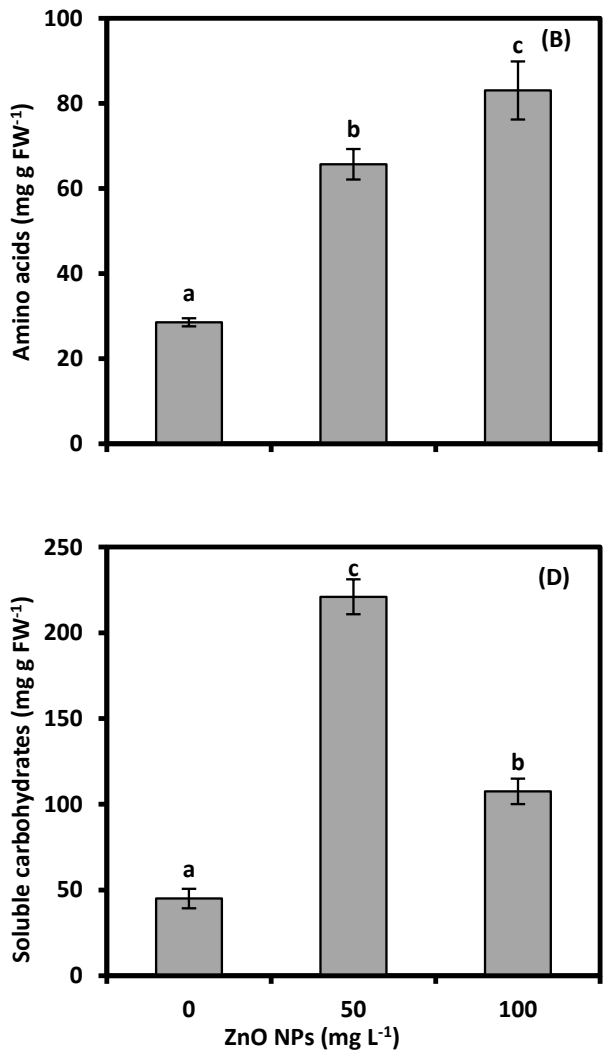

Fig. 3. Free and bound phenolic compounds (A), amino acids (B), soluble proteins (C) and soluble carbohydrates (D) of $S$. nigrum callus grown under different concentrations of ZnO NPs $\left(0,50\right.$, and $\left.100 \mathrm{mg} \mathrm{L}^{-1}\right)$ [The data are means \pm SD $(n=4)$. Different letters (small for free and capital for bound phenolic compounds) indicate statistically significant differences between different treatments according to the Tukey's HSD test $(\mathbf{P} \leq \mathbf{0 . 0 5})]$. 
Effects of $\mathrm{ZnO}$ NPs on amino acids, soluble proteins, and soluble carbohydrates

As shown in Fig. 3B, the amino acid content was increased by 130.05 and $190.81 \%$ with the exposure to 50 and $100 \mathrm{mg} \mathrm{L}^{-1} \mathrm{ZnO} \mathrm{NPs}$, respectively, relative to the control. The results also showed that amino acids were significantly correlated with zinc content in callus tissue $\left(0.897^{* *}\right)$.

Similarly, ZnO NPs enhanced the accumulation of soluble proteins within $S$. nigrum callus tissues (Fig. 3C). Its accumulation was found to be 62.60 and $91.46 \%$, after exposure to 50 and $100 \mathrm{mg} \mathrm{L}^{-1}$ $\mathrm{ZnO}$ NPs, respectively, compared with controls. Furthermore, the content of soluble proteins was significantly correlated with $\mathrm{Zn}$ concentration of the callus $(0.912 * *)$.

The soluble carbohydrates content of $S$. nigrum tissues was considerably increased when plants were exposed to the different concentrations of $\mathrm{ZnO}$ NPs (Fig. 3D). Compared to the control, the recorded highest increase was $390.69 \%$ at $50 \mathrm{mg} \mathrm{L}^{-1} \mathrm{ZnO}$ NPs. The accumulation of soluble carbohydrates was notably correlated with DW $(0.799 * *)$ and negatively with $\mathrm{K}$ content $(-0.720 *)$.

\section{Effects of $\mathrm{ZnO} N P S$ on some essential minerals} elements

$\mathrm{ZnO}$ NPs treatments differently affected some of the essential nutrients present in callus tissues as shown in the current study (Fig. 4A-C). The content of $\mathrm{P}$ in callus tissues was reduced by $39.06 \%$ and $53.87 \%$ under 50 and $100 \mathrm{mg} \mathrm{L}^{-1} \mathrm{ZnO} \mathrm{NPs}$, respectively, relative to the control. The results further revealed that the $\mathrm{P}$ content strongly negative correlated with the content of $\mathrm{Zn}^{+2}\left(-0.876^{* *}\right)$.

Regarding the content of $\mathrm{K}^{+}$in callus tissues, a decrease of $48.72 \%$ and $53.36 \%$ was observed after the application of 50 and $100 \mathrm{mg} \mathrm{L}^{-1} \mathrm{ZnO}$ NPs, respectively, compared with controls. Moreover, data revealed that the contents of $\mathrm{K}^{+}$and $\mathrm{Zn}^{+2}$ have a strong negative correlation with each other $\left(-0.786^{*}\right)$

As seen in Figure 4C, the accumulation of $\mathrm{Zn}^{+2}$ was concentration-dependent. The results manifested an increase in $\mathrm{Zn}^{+2}$ content in $S$. nigrum calli by increasing the concentration of $\mathrm{ZnO}$ NPs within MS media reaching up to 2.2 and 4.8 fold, under 50 and $100 \mathrm{mg} \mathrm{L}^{-1}$ treatments, respectively, compared to the control.
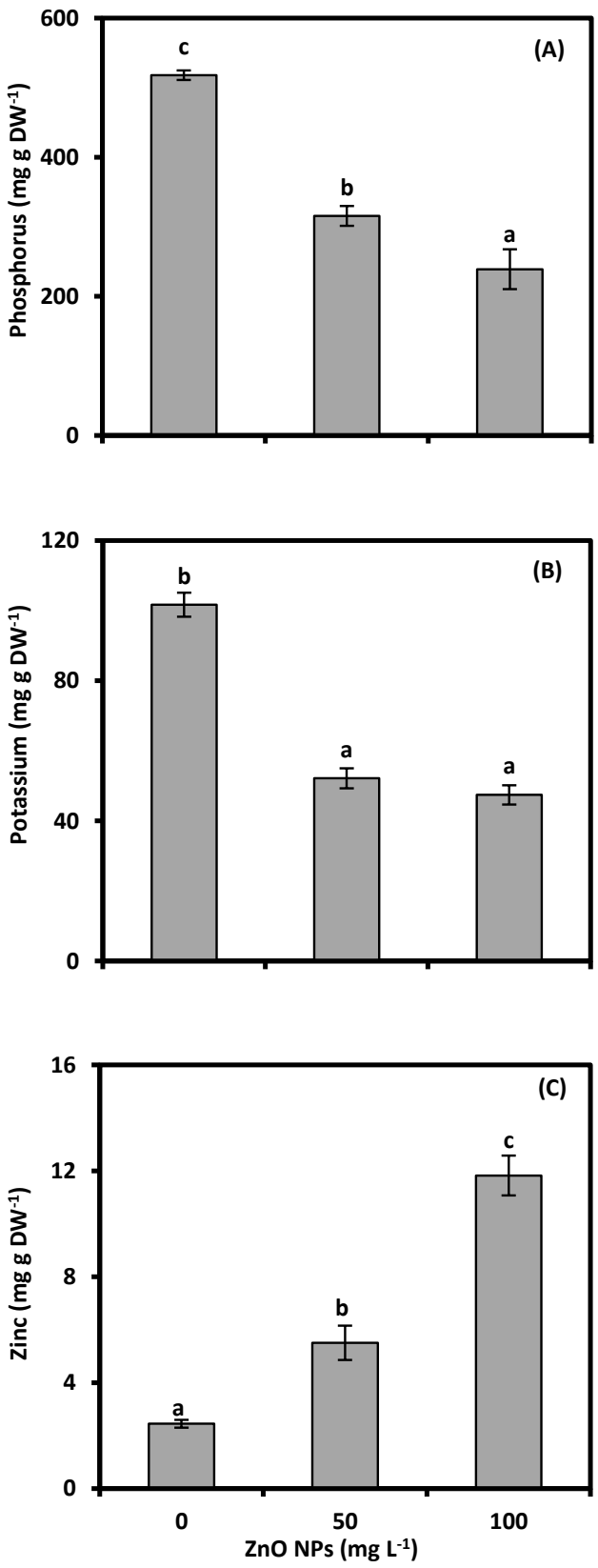

Fig. 4. Phosphorus (A), potassium (B) and zinc (C) contents of $S$. nigrum callus grown under different concentrations of $\mathrm{ZnO}$ NPs $(0$, 50 , and $100 \mathrm{mg}^{-1}$ ) [The data are means \pm SD $(n=4)$. Different letters indicate statistically significant differences according to the Tukey's HSD test $(\mathrm{P} \leq \mathbf{0 . 0 5})]$.

Effects of ZnO NPs on macromolecules

To study the structural changes in macromolecules of $S$. nigrum callus tissues exposed to different concentrations of $\mathrm{ZnO}$ NPs, the FT-IR was applied (Fig. 5A-I). The broadband $3342.96 \mathrm{~cm}^{-1}$ (control) was shifted by +30.65 and 
$+38.38 \mathrm{~cm}^{-1}$ when the callus was treated with 50 and $100 \mathrm{mg} \mathrm{L}^{-1} \mathrm{ZnO} \mathrm{NPs}$, respectively (Fig. 5A). The data in Fig. 5B, C, and E revealed that more or less no extended modifications were observed within the bands at 2929.53, 1653.24, and $1384.4 \mathrm{~cm}^{-1}$ with the application of various $\mathrm{ZnO}$ NPs levels. The transmittance area of the band at $1540.66 \mathrm{~cm}^{-1}$ (control) was disappeared under the treatment of $50 \mathrm{mg} \mathrm{L}^{-1} \mathrm{ZnO} \mathrm{NPs}$, whereas it was reduced by applying $100 \mathrm{mg} \mathrm{L}^{-1} \mathrm{ZnO}$ NPs $\left(-24.63 \mathrm{~cm}^{-1}\right.$ less than the transmittance area of control) (Fig. 5D). Compared to the control, $50 \mathrm{mg} \mathrm{L}^{-1} \mathrm{ZnO}$ NPs increased the transmission of the band at $1242.69 \mathrm{~cm}^{-1}$ by $+15.6 \mathrm{~cm}^{-1}$, while the highest concentration (100mg $\left.\mathrm{L}^{-1}\right)$ slightly reduced the transmission by $0.81 \mathrm{~cm}^{-1}$ (Fig. 5F).

Carbohydrates, proteins, alcohols and phenolic compounds

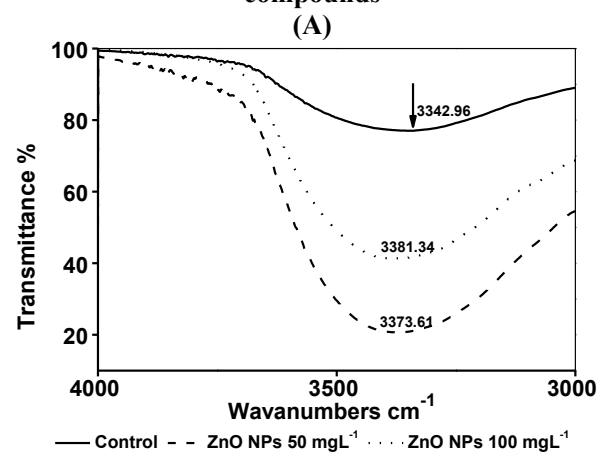

Amide I

(C)

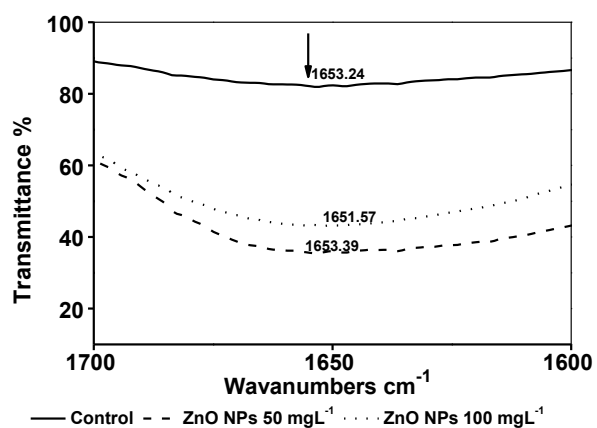

Amide III

(E)

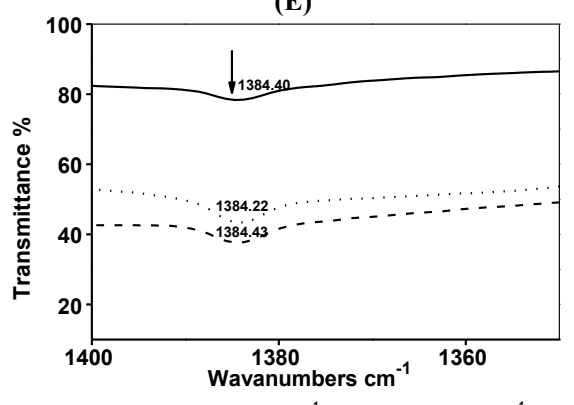

—Control - - ZnONPs $50 \mathrm{mgL}^{-1} \ldots$ ZnO NPs $100 \mathrm{mgL}^{-1}$
Treatment with $50 \mathrm{mg} \mathrm{L}^{-1} \mathrm{ZnO}$ NPs shifted the band at $1055.13 \mathrm{~cm}^{-1}$ (control) by $-15.3 \mathrm{~cm}^{-1}$, whereas the highest concentration $\left(100 \mathrm{mg} \mathrm{L}^{-1}\right)$ increased the transmission area by $+5.3 \mathrm{~cm}^{-1}$, relative to the control (Fig. $5 \mathrm{G}$ ). The weak sharp band at $824.84 \mathrm{~cm}^{-1}$ (control) disappeared by the application of $50 \mathrm{mg} \mathrm{L}^{-1} \mathrm{ZnO}$ NPs, while shifted $\left(+7.61 \mathrm{~cm}^{-1}\right)$ by applying the highest concentration (100 $\mathrm{mg} \mathrm{L}^{-1}$ ) (Fig. 5H). Furthermore, the week sharp band at $778.66 \mathrm{~cm}^{-1}$ (control) disappeared by applying ZnO NPs (Fig. 5I). Finally, the shift in the weak sharp band at $610.32 \mathrm{~cm}^{-1}$ was observed under $\mathrm{ZnO}$ NPs treatments $\left(+7.19\right.$ and $+9.02 \mathrm{~cm}^{-1}$, over the control at 50 and $100 \mathrm{mg} \mathrm{L}^{-1}$, respectively) (Fig. 5I).
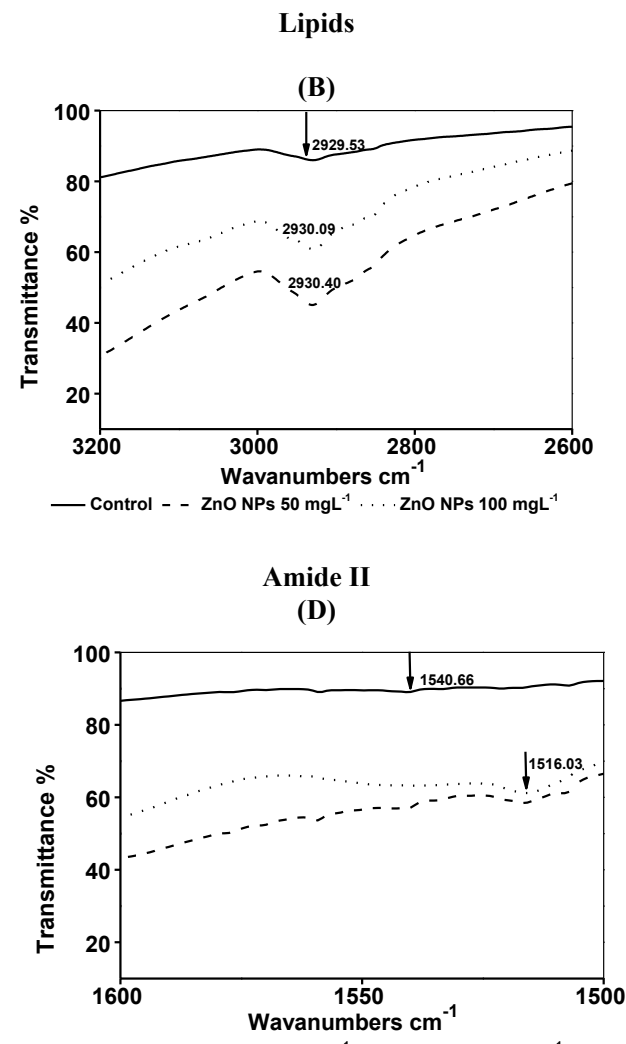

— Control - - ZnO NPs $50 \mathrm{mgL}^{-1} \ldots$ ZnO NPs $100 \mathrm{mgL}^{-1}$

Cellulose and hemicellulose

(F)

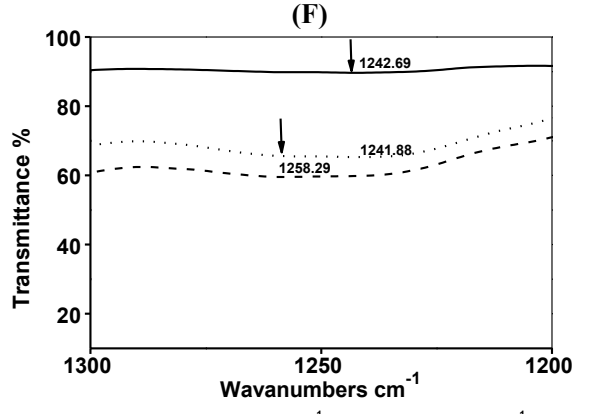

—Control - - ZnO NPs $50 \mathrm{mgL}^{-1} \ldots$ ZnO NPs $100 \mathrm{mgL}^{-1}$ 
Cellulose and hemicellulose

(G)

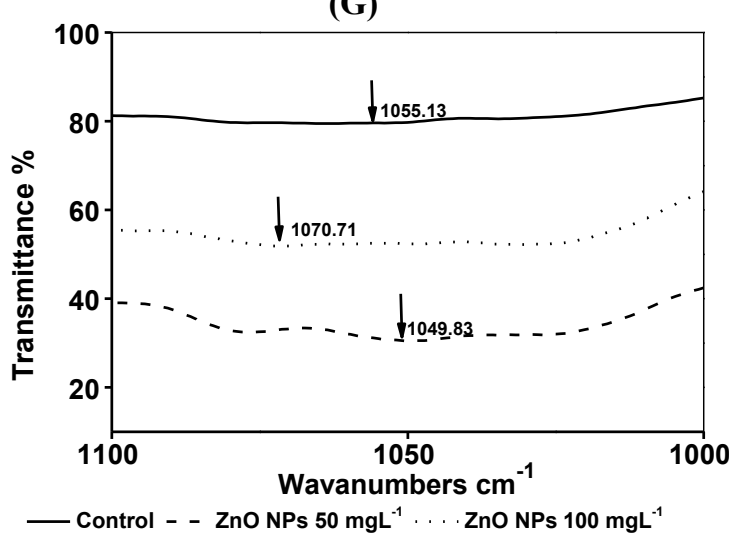

Carbohydrates

(H)

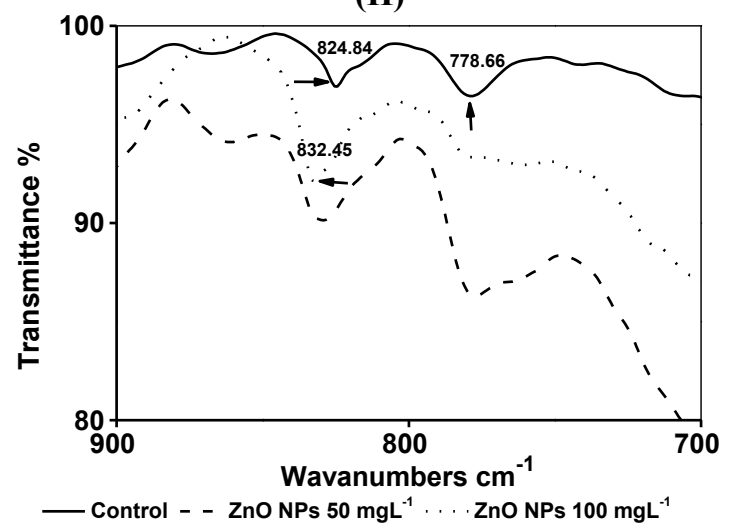

Aromatic compounds

(I)

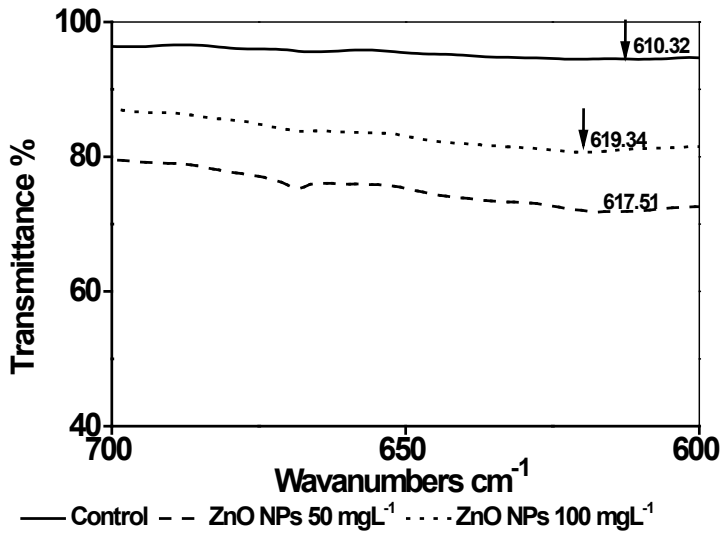

Fig. 5. FT-IR spectra of $S$. nigrum callus grown under different concentrations of $\mathrm{ZnO} \mathrm{NPs}(0,50$, and $100 \mathrm{mg}$ $\left.\mathrm{L}^{-1}\right)$. Spectral region associated with carbohydrates, proteins, alcohols, phenolic compounds (A), lipids (B), proteins (amide I) (C), amide II (D), amide III (E), cellulose and hemicellulose (F, G), carbohydrates (H), and aromatic compounds (I).

Interestingly, treatments with $\mathrm{ZnO} \mathrm{NPs}$ increased the intensity of all FT-IR bands over the control. Compared to the control, the highest intensity of all bands was recorded in the treatment of $50 \mathrm{mg} \mathrm{L}^{-1} \mathrm{ZnO}$ NPs.

\section{Discussion}

\section{Effects of ZnO NPs on biomass}

Under these experimental conditions, the lowest concentration of $\mathrm{ZnO}$ NPs significantly stimulated the callus growth, while the DW at the highest concentration of $\mathrm{ZnO}$ NPs was reduced. The stimulation of growth may suggest the ability of this callus to tolerate the toxicity of low concentrations of $\mathrm{ZnO}$ NPs. The negative weak correlation $(-0.437)$ between DW and $\mathrm{Zn}$ concentration may confirm this suggestion. Similarly, Zafar et al. (2016) reported that the rise in Brassica nigra shoot length in response to $\mathrm{ZnO}$ NPs could be the nutrition action of particles or dissociated ions only at a non-lethal level. In contrast, growth suppression is a common phenomenon in the case of $\mathrm{Zn}$ toxicity (Collins \& Zinc, 1981). The reduction in calli growth may additionally result from changes in the ultrastructure of the cells (Radi et al., 2018) or the arrest of cellular division (Ghosh et al., 2016).

Effects of ZnO NPS on the activity of the enzymes

The data presented here clarified an insignificant increase in LOX activity at $50 \mathrm{mg}$ $\mathrm{L}^{-1} \mathrm{ZnO}$ NPs, while the highest concentration of $\mathrm{ZnO}$ NPs showed a significant increase, relative to the control. In line with these findings, Tripathi et al. (2006) reported that the activity of LOX was increased by $\mathrm{Zn}$, which stimulated lipid peroxidation in membranes. 
The response of the antioxidant enzymes activities in the $S$. nigrum callus was based on the applied $\mathrm{ZnO}$ NPs concentrations. Feigl et al. (2015) reported that the ROS synthesis by $\mathrm{Zn}$ treatment changed the antioxidant capacity in Brassica juncea. In-plant cells, the SOD constitutes the prime line of defence versus ROS (Alscher et al., 2002). In the current study, the lowest level of $\mathrm{ZnO}$ NPs failed to exert a significant stimulation on the activity of SOD, while the highest level resulted in a significant one. These results suggested that ZnO NPs at $50 \mathrm{mg} \mathrm{L}^{-1}$ would possibly haven't toxic impacts on $S$. nigrum callus tissues. The strong positive correlations of SOD with the tested antioxidant enzymes may justify the strength of $S$. nigrum calli to resist $\mathrm{ZnO}$ NPs toxicity. The result is in line with recent findings of Wang et al. (2018) who reported that there was an increase in SOD activity with increased $\mathrm{ZnO}$ NPs concentrations in the nutrient medium of Solanum lycopersicum plants.

In the current study, the highest level of $\mathrm{ZnO}$ NPs caused significant stimulation of CAT activity, while the lower level failed to exert significant stimulation. This result may reveal that the highest concentration of $\mathrm{Zn}$ stimulated the active oxygen species, so stimulated SOD activity that produced excessive $\mathrm{H}_{2} \mathrm{O}_{2}$ which increased CAT activity (Wang et al., 2018).

In this study, the presence of $50 \mathrm{mg} \mathrm{L}^{-1} \mathrm{ZnO}$ NPs within the culture medium considerably failed to affect on POD activity of $S$. nigrum calli, therefore, no oxidative stress may be exerted in calli. Nonetheless, the higher POD activity observed under 100mg $\mathrm{L}^{-1} \mathrm{ZnO}$ NPs might suggest the role of this enzyme as a defence against ZnO NPs-caused oxidative damage. Also, POD activity exhibited a significant increasing trend when Allium cepa root cells were exposed to $\mathrm{ZnO}$ NPs (Ghosh et al., 2016).

\section{Effects of ZnO NPs on free and bound phenolics and associated enzymes}

In this study, $\mathrm{ZnO}$ NPs treatments did not alter PAL activity and phenolic contents (free and bound) in $S$. nigrum callus, whereas PPO activity was reduced. The data suggest that one probable reason for the plant resistance to $\mathrm{ZnO}$ NPs stress may be related to the unchanged PAL activity and phenolic compounds as well as the reduced PPO activity. Also, Zafar et al. (2016) and
Mohsenzadeh \& Moosavian (2017) found that exposure to $\mathrm{ZnO}$ NPs did not cause differences in total phenolic compounds in Brassica nigra shoot and rosemary seedling, compared to controls. The negative correlations between PPO and POD activities further confirm earlier reports of Sofo et al. (2005) who suggested that reduced PPO activity, which caused abiotic stress, is associated with improved antioxidant capacity.

Effects of $\mathrm{ZnO}$ NPs on amino acids, soluble proteins, and carbohydrates

Amino acids help to trap and chelate the metal ion, thus giving plants the ability to tolerate heavy metals (Singh et al., 2016). The obtained increase in free amino acids in callus tissues under the influence of $\mathrm{ZnO}$ NPs may indicate that these metabolites are involved in the high ability of $S$. nigrum to accumulate this metal. In this context, Kozhevnikova et al. (2014) reported that histidine was involved in $\mathrm{Zn}$ transport within the plant.

The noticed increase in protein concentration in plants exposed to $\mathrm{Cu}$ and $\mathrm{Zn}$ NPs by Olkhovych et al. (2016) was confirmed with the present results that showed an increase in the soluble protein content in the $S$. nigrum callus under different concentrations of $\mathrm{ZnO}$ NPs. Furthermore, Priyanka \& Venkatachalam (2016) suggested that improvements in the soluble protein content may protect cells from oxidative stress caused by $\mathrm{ZnO}$ NPs.

Soluble carbohydrates accumulate through many abiotic stress conditions along with oxidative stresses (Couée et al., 2006), suggesting a relationship between carbohydrates and ROS accumulation caused by intra-plant stresses. Recently, Gautam et al. (2019) reported that sucrose acts as a signal molecule against ROS besides that it is an energy source. The significant increase in the accumulation of soluble carbohydrates in the current experiment can be associated with its role as stress management and osmolytes needed for growth. High sucrose level in plant tissues has been reported under abiotic stress that indicates direct/indirect sugar involvement in stress management (Tognetti et al., 1990; Sami et al., 2016). The strong positive correlation between carbohydrates and the DW could confirm previous reports of Mukhopadyay et al. (2012) who concluded that soluble carbohydrates may be providing the energy and osmolytes needed for growth. 
Effects of ZnO NPs on some essential minerals elements

Potassium has a protective role against abiotic/biotic stresses, as $\mathrm{K}$ reduces the activity of nicotinamide adenine dinucleotide phosphate (NADPH) oxidase, which reduces the generation of ROS in plants (Hasanuzzaman et al., 2018). In this work, the different concentrations of $\mathrm{ZnO}$ NPs significantly reduced the K content in the $S$. nigrum callus. This result was confirmed by the resultant significant negative correlations between concentrations of $\mathrm{K}, \mathrm{LOX}$, and $\mathrm{Zn}$. In this regard, Tewari et al. (2004) reported that the accumulation of $\mathrm{Zn}$ leads to a deficit of ions and that is why it affects plant growth. In line with the obtained results, Zhao et al. (2012) recorded that Zn uptake is associated with considerable reductions in the content of macronutrients, such as $\mathrm{S}, \mathrm{K}$, and $\mathrm{Ca}$, referring that $\mathrm{Zn}$ disturbs ionic homeostasis that harms the plant by inducing oxidative damages.

Several studies disclose the negative correlation between the accumulation of inorganic $\mathrm{P}$ and $\mathrm{Zn}$ in the different plant species (Wang et al., 2009; Bouain et al., 2014). In agreement with these studies, the present finding revealed that the content of $\mathrm{P}$ in $S$. nigrum callus tissues gradually decreased with increasing ZnO NPs concentrations in the nutrient media. Strong negative correlations between the content of $\mathrm{P}$, the activities of LOX, SOD, CAT, POD, and Zn content may confirm that $\mathrm{Zn}$ considerably disturbs the $\mathrm{P}$ homeostasis, which increases the toxicity of $\mathrm{Zn}$ in plants.

Zinc is a necessary micronutrient, and shows a significant role in plant metabolism, while excess $\mathrm{Zn}$ may also have negative effects on the plant (Cakmak, 2000). In this research, the accumulated $\mathrm{Zn}$ in the $S$. nigrum callus by the increase in levels of $\mathrm{ZnO}$ NPs was insignificantly correlated with the DW of callus, while it was significantly correlated with LOX activity that could confirm the tolerance of $S$. nigrum to the toxicity of $\mathrm{ZnO}$ NPs. An increase in $\mathrm{Zn}$ accumulation was also reported during the stress of $\mathrm{ZnO}$ NPs on the pomegranate callus (Radi et al., 2018).

\section{Effects of $\mathrm{ZnO} N P$ s on macromolecules}

The FT-IR analysis regarding $S$. nigrum callus tissues allowed us to get more details about the construction adaptations of macromolecules under the effect of $\mathrm{ZnO}$ NPs. The initial peak at $3342.96 \mathrm{~cm}^{-1}$ (control) is stretched N-H and O-H groups associated with proteins, carbohydrates, alcohols, and phenolic compounds (Türker-Kaya \& Huck, 2017). The obtained data showed that exposure of the callus to $\mathrm{ZnO}$ NPs increased the transmittance area and intensity, and this increase could indicate that additional $\mathrm{O}-\mathrm{H}$ groups were formed to chelate $\mathrm{Zn}$. It was earlier reported that the low concentration $\left(10 \mathrm{mg} \mathrm{L}^{-1}\right)$ of $\mathrm{ZnO}$ NPs led to a positive shift and high intensity of this band in pomegranate calli, whereas the high concentration (150 $\mathrm{mg} \mathrm{L}^{-1}$ ) caused the opposite effect (Radi et al., 2018).

Fatty acids show characteristic transmittance peak at $2950-2845 \mathrm{~cm}^{-1}$ (Gupta et al., 2015). In this investigation, the different concentrations of $\mathrm{ZnO}$ NPs did not induce noticeable shifts at the peak of the fatty acids, whereas the intensity of that peak was increased. This change in the intensity of peaks might reveal that $\mathrm{ZnO}$ NPs changed the composition of fatty acids. In line with this result, Radi et al. (2018) showed that ZnO NPs did not induce a noticeable shift at this peak.

The peak at $1653.24 \mathrm{~cm}^{-1}$ (control) is ascribed to $\mathrm{C}=\mathrm{O}$ stretching ordinarily conjugated according to a -NH deformation mode, and might also ascribe to the amide I peak ( $\alpha$-helix structure) (Hlihor et al., 2013). In this study, the slight shift within the amide I peak under the highest level of $\mathrm{ZnO}$ NPs may indicate some changes in the structure of calli proteins. In this context, Surewicz et al. (1993) stated that the limit in the peak area may detect modifications between protein content and structure, possibly due to the toxicity of metals. On the other hand, the resultant increase in the peak intensity under $\mathrm{ZnO}$ treatments agree with the previous report of Nahar \& Tajmir-Riahi (1996) who concluded that the rise in the intensity of amide I peak, is considered as a consequence of a direct heavy metal $(\mathrm{Cd})$ - protein binding by the peptide carbonyl group. The peak around 1540.66 $\mathrm{cm}^{-1}$ is assigned as amide II, which collaborated in the motion combining both $-\mathrm{NH}$ bending and -CN stretching vibration of the group $\mathrm{C}(=\mathrm{O})-\mathrm{NH}$ in its transform (Pan et al., 2007). Under ZnO NPs treatments, this peak disappeared at the lowest level, while at the highest level it was reduced. These changes might be attributed to the change in amide II under $\mathrm{ZnO}$ NPs stress. The increased intensity of the $1384.40 \mathrm{~cm}^{-1}$ peak, which is related to the amide III (Fawzy, 2016), under ZnO NPs treatments could be linked to $\mathrm{Zn}$-binding proteins.

The peak at $1242.69 \mathrm{~cm}^{-1}$ is pointed to 
stretching vibration $\mathrm{C}-\mathrm{O}$ that identifies the existence of cellulose and hemicellulose (Rico et al., 2015). ZnO NPs at 50mg $\mathrm{L}^{-1}$ raised the transmittance of that peak, whereas $100 \mathrm{mg} \mathrm{L}^{-1}$ slightly reduced the transmittance. The shift and height of this peak intensity can be indicated in the change and participation of $\mathrm{C}-\mathrm{O}$ polysaccharides in the accumulation of $\mathrm{Zn}$ on the cell wall (Radi et al., 2018).

The decrease in the peak area $1055.13 \mathrm{~cm}^{-1}$ could suggest a decrease in the synthesis of cellulose, hemicellulose and carbohydrates that are participated in cell growth (Rico et al., 2015). Furthermore, the increase in the peak intensity under $\mathrm{ZnO}$ NPs treatments may be caused by the participation of $\mathrm{C}=\mathrm{O}$ of polysaccharides within the accumulation of $\mathrm{Zn}$ on the cell wall (Radi et al., 2018). The peaks at 824.84 and $778.66 \mathrm{~cm}^{-1}$, which were found in control and $100 \mathrm{mg} \mathrm{L}^{-1} \mathrm{ZnO}$, respectively, are normally attributed to carbohydrates (Schrader, 1995). These results might indicate the synthesis of extra carbohydrates under an excessive level of ZnO NPs (Fawzy, 2016). The increase in the transmittance area at $610.32 \mathrm{~cm}^{-1}$ that is indicated to aromatic compounds (Ramamurthy \& Kannan, 2007), might suggest chelation of $\mathrm{ZnO}$ NPs.

Interestingly, $\mathrm{ZnO}$ NPs treatments increased the intensity of all FT-IR peaks over the control. Compared to the control, the highest intensity for all peaks was recorded in the treatment of $50 \mathrm{mg} \mathrm{L}^{-1} \mathrm{ZnO}$ NPs. This result may reveal that the high peak intensity plays an important role in the chelation of excess Zn. Fawzy (2016) stated that the increase in peak intensity may indicate the interaction of amino, carboxyl, hydroxyl, thiol and phosphate groups with heavy metals.

\section{Conclusion}

The results of this study revealed the stimulation of growth by the lowest concentration $(50 \mathrm{mg}$ $\left.\mathrm{L}^{-1}\right)$ of $\mathrm{ZnO}$ NPs. The tolerance of $S$. nigrum calli to $\mathrm{ZnO}$ NPs can be attributed to the antioxidant systems, free amino acids, soluble proteins, and soluble carbohydrates. Furthermore, FT-IR analysis indicated the role of macromolecules in the $\mathrm{ZnO}$ NPs chelating process. The current results showed that the $S$. nigrum callus may be able to resist the toxicity of $\mathrm{ZnO} N \mathrm{NP}$, this means that it can be used in the remediation of $\mathrm{ZnO}$ NPs from contaminated media.
Acknowledgements: This work was carried out in Genetic Engineering and Tissue Culture Research Unit at Assiut University. The authors are grateful to Dr Mokhtar Mamdouh Shaaban and all members of this unit.

\section{References}

Abdel-Wahab, D.A., Othman, N.A.R.M., Hamada, A.M. (2019) Effects of copper oxide nanoparticles to Solanum nigrum and its potential for phytoremediation. Plant Cell, Tissue and Organ Culture, 137, 525-539.

Aebi, H. (1984) Catalase in vitro. Methods in Enzymology, 105, 121-126.

Alscher, R.G., Erturk, N., Heath, L.S. (2002) Role of superoxide dismutases (SODs) in controlling oxidative stress in plants. Journal of Experimental Botany, 53, 1331-1341.

Bouain, N., Shahzad, Z., Rouached, A., Khan, G.A., Berthomieu, P., Abdelly, C., Poirier, Y., Rouached, H. (2014) Phosphate and zinc transport and signalling in plants: toward a better understanding of their homeostasis interaction. Journal of Experimental Botany, 65, 5725-5741.

Cakmak, I. (2000) Possible roles of zinc in protecting plant cells from damage by reactive oxygen species. New Phytologist, 146, 185-205.

Collins, J., Zinc, C. (1981) "Effects of Heavy Metal Pollution on Plants", Ed. Publishe, London.

Couée, I., Sulmon, C., Gouesbet, G., El Amrani, A. (2006) Involvement of soluble sugars in reactive oxygen species balance and responses to oxidative stress in plants. Journal of Experimental Botany, 57, 449-459.

Fales, F. (1951) The assimilation and degradation of carbohydrates by yeast cells. Journal of Biological Chemistry, 193, 113-124.

Fawzy, M.A. (2016) Phycoremediation and adsorption isotherms of cadmium and copper ions by Merismopedia tenuissima and their effect on growth and metabolism. Environmental Toxicology and Pharmacology, 46, 116-121.

Feigl, G., Lehotai, N., Molnár, Á., Ördög, A., Rodríguez-Ruiz, M., Palma, J.M., Corpas, F.J., 
Erdei, L., Kolbert, Z. (2015) Zinc induces distinct changes in the metabolism of reactive oxygen and nitrogen species (ROS and RNS) in the roots of two Brassica species with different sensitivity to zinc stress. Annals of Botany, 116, 613-625.

Garbisu, C., Alkorta, I. (2003) Basic concepts on heavy metal soil bioremediation. European Journal of Mineral Processing and Environmental Protection, 3, 58-66.

Gautam, A., Kumar, N., Dubey, A.K., Ranjan, R., Sahu, N., Behera, S.K., Shah, K., Tripathi, R.D., Mallick, S. (2019) Sucrose plays key role in amelioration of arsenic induced phytotoxicity through modulating phosphate and silicon transporters, physiological and biochemical responses in $\mathrm{C} 3$ (Oryza sativa L.) and C4 (Zea mays L.). Environmental and Experimental Botany, 171, 103930.

Ghosh, M., Jana, A., Sinha, S., Jothiramajayam, M., Nag, A., Chakraborty, A., Mukherjee, A., Mukherjee, A. (2016) Effects of $\mathrm{ZnO}$ nanoparticles in plants: cytotoxicity, genotoxicity, deregulation of antioxidant defenses, and cell-cycle arrest. Mutation Research - Genetic Toxicology and Environmental Mutagenesis, 807, 25-32.

Gupta, B.S., Jelle, B.P., Gao, T. (2015) Application of ATR-FTIR spectroscopy to compare the cell materials of wood decay fungi with wood mould fungi. International Journal of Spectroscopy, 2015, $1-7$.

Hasanuzzaman, M., Bhuyan, M., Nahar, K., Hossain, M., Mahmud, J., Hossen, M., Masud, A., Fujita, M. (2018) Potassium: A vital regulator of plant responses and tolerance to abiotic stresses. Agronomy, 8, 1-29.

Havir, E.A., Hanson, K.R. (1968) L-Phenylalanine ammonia-lyase. II. Mechanism and kinetic properties of the enzyme from potato tubers. Biochemistry, 7, 1904-1914.

Hlihor, R., Diaconu, M., Fertu, D., Chelaru, C., Sandu, I., Tavares, T. (2013) Bioremediation of $\mathrm{Cr}$ (VI) polluted wastewaters by sorption on heat inactivated Saccharomyces cerevisiae biomass. International Journal of Environmental Research, 7, 581-594.

Housseiny, M.M., Gomaa, E.Z. (2019) Enhancement of antimicrobial and antitumor activities of zinc nanoparticles biosynthesized by Penicillium chrysogenum AUMC 10608 using gamma radiation. Egyptian Journal of Botany, 59(2), 319- 337.

Ju-Nam, Y., Lead, J.R. (2008) Manufactured nanoparticles: an overview of their chemistry, interactions and potential environmental implications. Science of the Total Environment, 400, 396-414.

Kofalvi, S., Nassuth, A. (1995) Influence of wheat streak mosaic virus infection on phenylpropanoid metabolism and the accumulation of phenolics and lignin in wheat. Physiological and Molecular Plant Pathology, 47, 365-377.

Kozhevnikova, A.D., Seregin, I.V., Erlikh, N.T., Shevyreva, T.A., Andreev, I.M., Verweij, R., Schat, H. (2014) Histidine-mediated xylem loading of zinc is a species-wide character in Noccaea caerulescens. New Phytologist, 203, 508-519.

Kumar, A., Gupta, K., Dixit, S., Mishra, K., Srivastava, S. (2019) A review on positive and negative impacts of nanotechnology in agriculture. International Journal of Environmental Science and Technology, 16, 2175-2184.

Kumar, K., Khan, P. (1982) Peroxidase and polyphenol oxidase in excised ragi (Eleusine corocana cv PR 202) leaves during senescence. Indian Journal of Experimental Biology, 20, 412-416.

Lowry, O., Rosebrough, N., Farr, A., Randall, R. (1951) Protein measurement with Folin-phenol reagent. The Journal of Biological Chemistry, 193, 265275.

Marques, A.P., Oliveira, R.S., Rangel, A.O., Castro, P.M. (2006) Zinc accumulation in Solanum nigrum is enhanced by different arbuscular mycorrhizal fungi. Chemosphere, 65, 1256-1263.

Minguez-Mosquera, M., Jaren-Galan, M., GarridoFernandez, J. (1993) Lipoxygenase activity during pepper ripening and processing of paprika. Phytochemistry, 32, 1103-1108.

Misra, H.P., Fridovich, I. (1972) The role of superoxide anion in the autoxidation of epinephrine and a simple assay for superoxide dismutase. The Journal of Biological Chemistry, 247, 3170-3175.

Mkumbo, S., Mwegoha, W., Renman, G. (2012) Assessment of the phytoremediation potential for 
$\mathrm{Pb}, \mathrm{Zn}$ and $\mathrm{Cu}$ of indigenous plants growing in a gold mining area in Tanzania. International Journal of Environmental Science, 2, 2425-2434.

Mohsenzadeh, S., Moosavian, S.S. (2017) Zinc sulphate and nano-zinc oxide effects on some physiological parameters of Rosmarinus officinalis. American Journal of Plant Sciences, 8, 2635.

Moore, S., Stein, W. (1948) Photometric ninhydrin method for use in the chromatography of amino acids. The Journal of Biological Chemistry, 176, 367-387.

Morales-Díaz, A.B., Ortega-Ortíz, H., JuárezMaldonado, A., Cadenas-Pliego, G., GonzálezMorales, S., Benavides-Mendoza, A. (2017) Application of nanoelements in plant nutrition and its impact in ecosystems. Advances in Natural Sciences: Nanoscience and Nanotechnology, 8 , 1-13.

Mukhopadyay, M., Bantawa, P., Das, A., Sarkar, B., Bera, B., Ghosh, P., Mondal, T.K. (2012) Changes of growth, photosynthesis and alteration of leaf antioxidative defence system of tea [Camellia sinensis (L.) O. Kuntze] seedlings under aluminum stress. Biometals, 25, 1141-1154.

Murashige, T., Skoog, F. (1962) A revised medium for rapid growth and bio assays with tobacco tissue cultures. Physiologia Plantarum, 15, 473-497.

Nahar, S., Tajmir-Riahi, H. (1996) Complexation of heavy metal cations $\mathrm{Hg}, \mathrm{Cd}$, and $\mathrm{Pb}$ with proteins of PSII: evidence for metal-sulfur binding and protein conformational transition by FTIR spectroscopy. Journal of Colloid and Interface Science, 178, 648656.

Olkhovych, O., Volkogon, M., Taran, N., Batsmanova, L., Kravchenko, I. (2016) The effect of copper and zinc nanoparticles on the growth parameters, contents of ascorbic acid, and qualitative composition of amino acids and acylcarnitines in Pistia stratiotes L. (Araceae). Nanoscale Research Letters, 11, 218.

Pan, J.-h., Liu, R.-x., Tang, H.-x. (2007) Surface reaction of Bacillus cereus biomass and its biosorption for lead and copper ions. Journal of Environmental Sciences, 19, 403-408.

Pilon-Smits, E. (2005) Phytoremediation. Annual
Review of Plant Biology, 56, 15-39.

Priyanka, N., Venkatachalam, P. (2016) Biofabricated zinc oxide nanoparticles coated with phycomolecules as novel micronutrient catalysts for stimulating plant growth of cotton. Advances in Natural Sciences: Nanoscience and Nanotechnology, 7, 045018.

Radi, A.A., Farghaly, F.A., Al-Kahtany, F.A., Hamada, A.M. (2018) Zinc oxide nanoparticles-mediated changes in ultrastructure and macromolecules of pomegranate callus cells. Plant Cell, Tissue and Organ Culture, 135, 247-261.

Raliya, R., Franke, C., Chavalmane, S., Nair, R., Reed, N., Biswas, P. (2016) Quantitative understanding of nanoparticle uptake in watermelon plants. Frontiers in Plant Science, 7, 1288.

Ramamurthy, N., Kannan, S. (2007) Fourier transform infrared spectroscopic analysis of a plant (Calotropis gigantea Linn) from an industrial village, Cuddalore dt, Tamilnadu, India. Romanian Journal of Biophysics, 17, 269-276.

Rehman, M.Z.U., Rizwan, M., Ali, S., Ok, Y.S., Ishaque, W., Nawaz, M.F., Akmal, F., Waqar, M. (2017) Remediation of heavy metal contaminated soils by using Solanum nigrum: a review. Ecotoxicology and Environmental Safety, 143, 236-248.

Rico, A., Rencoret, J., José, C., Martínez, A.T., Gutiérrez, A. (2015) In-depth 2D NMR study of lignin modification during pretreatment of Eucalyptus wood with laccase and mediators. BioEnergy Research, 8, 211-230.

Sami, F., Yusuf, M., Faizan, M., Faraz, A., Hayat, S. (2016) Role of sugars under abiotic stress. Plant Physiology and Biochemistry, 109, 54-61.

Särkinen, T., Poczai, P., Barboza, G.E., van der Weerden, G.M., Baden, M., Knapp, S. (2018) A revision of the Old World black nightshades (Morelloid clade of Solanum L., Solanaceae). PhytoKeys, 2018(106), 1-223.

Schlegel, H. (1956) Die verwertung organischer säuren durch Chlorella im licht. Planta, 47, 510-526.

Schrader, B. (1995) "Infrared and Raman Spectroscopy: Methods and Applications", Ed. Publishe, New York 
Singh, A., Singh, N., Hussain, I., Singh, H., Yadav, V., Singh, S. (2016) Green synthesis of nano zinc oxide and evaluation of its impact on germination and metabolic activity of Solanum lycopersicum. Journal of Biotechnology, 233, 84-94.

Sofo, A., Dichio, B., Xiloyannis, C., Masia, A. (2005) Antioxidant defences in olive trees during drought stress: changes in activity of some antioxidant enzymes. Functional Plant Biology, 32, 45-53.

Surewicz, W.K., Mantsch, H.H., Chapman, D. (1993) Determination of protein secondary structure by Fourier transform infrared spectroscopy: A critical assessment. Biochemistry, 32, 389-394.

Tatiana, Z., Yamashita, K., Matsumoto, H. (1999) Iron deficiency induced changes in ascorbate content and enzyme activities related to ascorbate metabolism in cucumber roots. Plant and Cell Physiology, 40, 273-280.

Tewari, R.K., Kumar, P., Tewari, N., Srivastava, S., Sharma, P.N. (2004) Macronutrient deficiencies and differential antioxidant responses-influence on the activity and expression of superoxide dismutase in maize. Plant Science, 166, 687-694.

Tognetti, J., Salerno, C., Crespi, M., Pontis, H. (1990) Sucrose and fructan metabolism of different wheat cultivars at chilling temperatures. Physiologia Plantarum, 78, 554-559.

Tripathi, B., Mehta, S., Amar, A., Gaur, J. (2006) Oxidative stress in Scenedesmus sp. during short-and long-term exposure to $\mathrm{Cu}^{2+}$ and $\mathrm{Zn}^{2+}$. Chemosphere, 62, 538-544.

Türker-Kaya, S., Huck, C. (2017) A review of mid- infrared and near-infrared imaging: Principles, concepts and applications in plant tissue analysis. Molecules, 22, 168.

Wang, C., Zhang, S.H., Wang, P.F., Hou, J., Zhang, W.J., Li, W., Lin, Z.P. (2009) The effect of excess $\mathrm{Zn}$ on mineral nutrition and antioxidative response in rapeseed seedlings. Chemosphere, 75, 14681476.

Wang, X., Li, Q., Pei, Z., Wang, S. (2018) Effects of zinc oxide nanoparticles on the growth, photosynthetic traits, and antioxidative enzymes in tomato plants. Biologia Plantarum, 62, 801-808.

Woods, J., Mellon, M. (1941) Molybdenum blue reaction: A spectrophotometric study. Industrial \& Engineering Chemistry Analytical Edition, 13(11), 760-764.

Zafar, H., Ali, A., Ali, J.S., Haq, I.U., Zia, M. (2016) Effect of $\mathrm{ZnO}$ nanoparticles on Brassica nigra seedlings and stem explants: growth dynamics and antioxidative response. Frontiers in Plant Science, $7,1-8$.

Zaka, M., Abbasi, B.H., Rahman, L.-u., Shah, A., Zia, M. (2016) Synthesis and characterisation of metal nanoparticles and their effects on seed germination and seedling growth in commercially important Eruca sativa. IET Nanobiotechnology, 10, 134-140.

Zhao, H., Wu, L., Chai, T., Zhang, Y., Tan, J., Ma, S. (2012) The effects of copper, manganese and zinc on plant growth and elemental accumulation in the manganese-hyperaccumulator Phytolacca americana. Journal of Plant Physiology, 169, 1243-1252. 


\section{أكسيد الزنك النانو يستحث التغيرات في أنظمة مضادات الأكسدة والجزيئات الكبيرة في

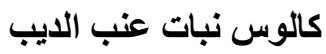

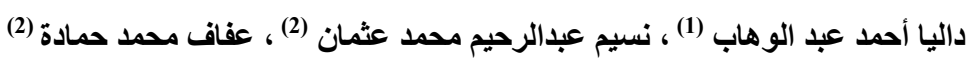

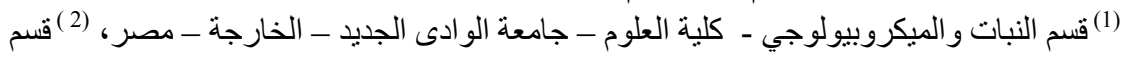 النبات و الميكروبيولوجي - كلية العلوم - جامعة أسيوط - أسيوط - مصر الكر.}

تهاف هذه الدر اسة إلى استكثاف آثار الجسيمات النانوية لأكسيد الزنك (ZnO NPs) على العمليات

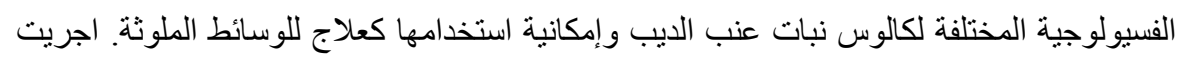

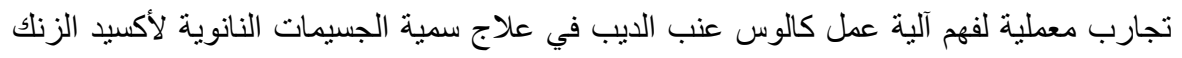

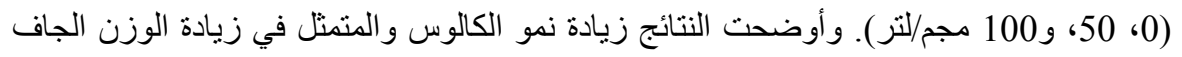

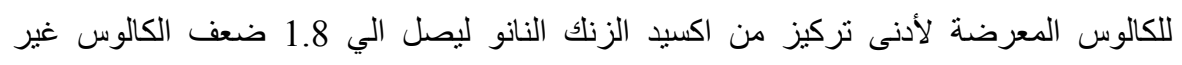

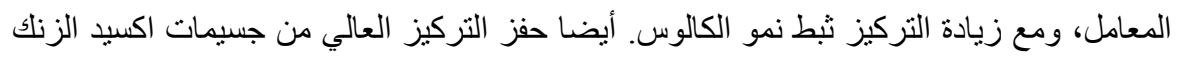
النانوية أنشطة إنزيمات الليبو جينيز والانزيمات المضادة للأكسدة في الكالوس. في حين معاملة اكسيد

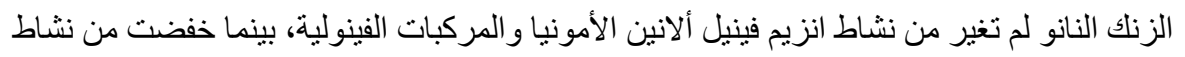

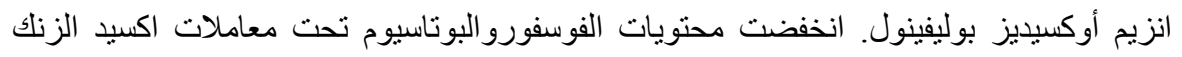

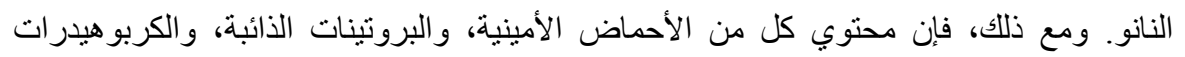

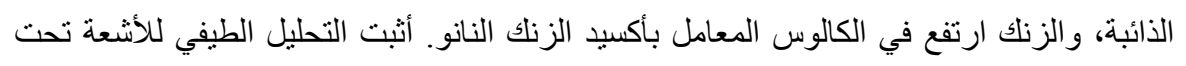

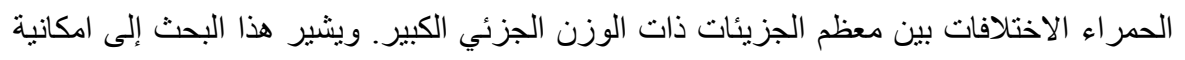

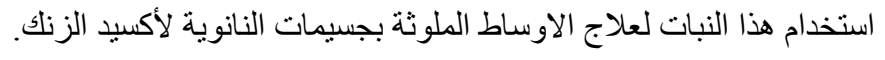

